\title{
Desenvolvimento de requeijão com extrato aquoso de semente de Moringa oleifera
}

\author{
Development of processed cheese with aqueous extract of Moringa oleifera seed \\ Elaboración de queso procesado con extracto acuoso de semilla de Moringa oleifera
}

Recebido: 28/03/2021 | Revisado: 04/04/2021 | Aceito: 11/04/2021 | Publicado: 22/04/2021

Laís Malachias Araújo

ORCID: https://orcid.org/0000-0002-3380-342X Universidade Estadual de Maringá, Brasil E-mail: laisaraujo_202020@outlook.com

Guilherme Eiki Ogusku Quintanilha

ORCID: https://orcid.org/0000-0002-4222-6548 Universidade Estadual de Maringá, Brasil E-mail: guilhermequinta@hotmail.com

Raquel Guttierres Gomes

ORCID: https://orcid.org/0000-0003-2420-5134 Universidade Estadual de Maringá, Brasil E-mail: rgutti02@gmail.com

Angélica Marquetotti Salcedo Vieira ORCID: https://orcid.org/0000-00017467-3767 Universidade Estadual de Maringá, Brasil E-mail: amsvieira@uem.br

\begin{abstract}
Resumo
Neste estudo o queijo fundido foi produzido com substituição total e parcial da goma xantana pelo extrato da semente de Moringa e armazenado a $4^{\circ} \mathrm{C}$. Foram estudados a composição química $\mathrm{pH}$, acidez, cor, textura e reologia. A composição química diferiu significativamente $(\mathrm{p}<0,05)$ entre as amostras. $\mathrm{O}$ teor de proteína foi maior para a amostra contendo apenas extrato de Moringa. A acidez diferiu significativamente $(p<0,05)$ apenas no último dia de armazenamento. Os valores de $\mathrm{pH}$ permaneceram dentro dos limites de qualidade estabelecidos $(\mathrm{pH} \geq 6,0)$ para todas as amostras durante os 21 dias de armazenamento. A adição do extrato afetou a cor e a microestrutura das amostras; Queijos processados com extrato adicionado apresentaram partículas de menor tamanho de glóbulos de gordura e distribuídos sem uniformidade. O extrato de Moringa interferiu na textura do produto, revelando-se um grande substituto parcial e / ou total dos conservantes químicos. A amostra com maior substituição de goma pelo extrato de Moringa teve dureza igual à amostra controle. Além disso, esta amostra (T4 - 0,15\% goma e 0,35\% extrato de Moringa) apresentou maior índice de consistência (K). As amostras não apresentaram diferenças significativas durante o período de armazenamento para coesividade. O perfil reológico mostrou que todas as amostras apresentaram um perfil não newtoniano (pseudoplástico). Dessa forma, acredita-se que a semente da Moringa tenha potencial para uso como substituto de espessante.
\end{abstract}

Palavras-chave: Queijo; Proteína; Emulsificante; Aditivo.

\begin{abstract}
In this study, processed cheese was produced with a total and partial substitution of xanthan gum by Moringa seed extract and stored at $4^{\circ} \mathrm{C}$. Chemical composition $\mathrm{pH}$, acidity, color, texture, and rheology were studied. The chemical composition differed significantly $(\mathrm{p}<0.05)$ between the samples. Protein content was higher for the sample containing only Moringa extract. The acidity differed significantly $(\mathrm{p}<0.05)$ only on the last day of storage. The $\mathrm{pH}$ values remained within the established quality limits $(\mathrm{pH} \geq 6.0)$ for all samples during the 21 days of storage. The addition of extract affected the color and microstructure of the samples; processed cheese with added extract showed smaller particle size fat globules and distributed without uniformity. The Moringa extract interfered in the texture of the product, proving to be a great partial and/or total substitute of chemical preservatives. The sample with greater gum substitution by the Moringa extract had hardness equal to the control sample. Also, this sample (T4 - 0.15\% gum and $0.35 \%$ Moringa extract) presented higher consistency index (K). Samples did not show significant differences during storage period for cohesiveness. The rheological profile showed that all samples presented a non-Newtonian (pseudoplastic) profile. Thus, it is believed that the Moringa seed has a potential for use as a thickener substitute.
\end{abstract}

Keywords: Cheese; Protein; Emulsifier; Additive.

\section{Resumen}

En este estudio, se produjo queso procesado con sustitución total y parcial de goma xantana por extracto de semilla de Moringa y se almacenó a $4^{\circ} \mathrm{C}$. Se estudió la composición química $\mathrm{pH}$, acidez, color, textura y reología. La composición química difirió significativamente $(\mathrm{p}<0.05)$ entre las muestras. El contenido de proteína fue mayor para 
la muestra que solo contenía extracto de Moringa. La acidez difirió significativamente $(\mathrm{p}<0.05)$ solo en el último día de almacenamiento. Los valores de $\mathrm{pH}$ se mantuvieron dentro de los límites de calidad establecidos $(\mathrm{pH} \geq 6.0)$ para todas las muestras durante los 21 días de almacenamiento. La adición de extracto afectó el color y la microestructura de las muestras; El queso procesado con extracto agregado mostró glóbulos de grasa de menor tamaño de partícula y se distribuyó sin uniformidad. El extracto de Moringa interfirió en la textura del producto, demostrando ser un gran sustituto parcial y / o total de los conservantes químicos. La muestra con mayor sustitución de goma por el extracto de Moringa tuvo una dureza igual a la muestra de control. Asimismo, esta muestra (T4 - $0.15 \%$ goma y $0.35 \%$ extracto de Moringa) presentó mayor índice de consistencia (K). Las muestras no mostraron diferencias significativas durante el período de almacenamiento para la cohesión. El perfil reológico mostró que todas las muestras presentaron un índice no newtoniano (pseudoplástico) perfil. Por lo tanto, se cree que la semilla de Moringa tiene potencial para usarse como un sustituto espesante.

Palabras clave: Queso; Proteína; Emulsionante; Aditivo.

\section{Introdução}

We note an increase in consumption per food product with functional properties, as in addition to being a source of essential nutrients and energy, they can be enriched with additives that are essential to improve human health (Colín-Cruz et al., 2019).

In the dairy products area, we can observe an increase in the versatility of products, mainly for yogurt and cheeses. Due to its versatility, cream cheese and creamy melted cheese has become one of the focuses in research in the production of functional and differentiated products (Vieira et al., 2014). Felix et al. (2016) clarifies that According to the Technical Regulation for the Identification and Quality of Curd, Curd is defined as the product obtained from the coagulation of milk, which may be acidic or enzymatic followed by the melting of curd, removal of whey and washing, and the addition of cream of milk, butter or butter oil in its composition according to the Brazilian Legislation.

Due to cost reduction in production, nowadays there is a series of similar products using the same process (Torres et al., 2015). Even though the modified processed cheese has non-dairy ingredients, they have similar sensorial characteristics to the traditional ones. In addition to reducing costs, ingredients substitution can result in other benefits such as improving the nutritional and functional characteristics of the product (Belsito et al., 2017)

In this context, studies of protein sources have increased in order to apply their technological properties in food processing ( Mao et al., 2018).

Moringa (Moringa oleifera) is a tropical plant known for its high nutritional value (Gopalakrishnan et al., 2016). Moringa seeds are recognized for having antimicrobial, antioxidant, and nutritional properties, and a significant amount of lipids and proteins (Gupta et al., 2017). According to Baptista et al. (2015), moringa seeds contain high levels of proteins, approximately $45 \%$ of their constitution. Some of these proteins able to interact with sugars through hydrogen bonding, hydrophobic interactions and Van der Waals forces promoting agglutination (Yeh et al., 2014). Moreover, chemical composition studies of this plant have identified several bioactive substances that can be used in various industrial applications (Gupta et al., 2017).

Ultrafiltration is an effective alternative for concentrating/purifying numerous proteins based on their molar mass. However, despite its extensive use, the protein fractionation potential has not yet been explored in the industry (Baptista et al., 2017).

Understanding the functional properties and behavior of proteins is important to the technological development of the food industries, once these compounds become alternative sources of protein and chemical compounds substitutes resulting in cost reductions (Mao et al., 2018).

Therefore, based on the importance of proteins for the industry, the objective of this study was to evaluate the total and partial substitution of xanthan gum, a thickener agent, by the Moringa extract ultrafiltrate in processed cheese. The product composition, physical, texture, rheological and microstructural properties of processed cheese were evaluated. 


\section{Metodologia}

\subsection{Material}

Moringa seeds were obtained in Aracaju - SE, located between 10 $55^{\prime} 56$ "south of the geographical coordinate latitude and 37 $04^{\prime} 23^{\prime \prime}$ west longitude. Xanthan gum (Rhodigel 80) was donated by Danisco®, and nisin and fondant salt (R9) donated by Simionato Leite Vida Ativa ${ }^{\circledR}$. Milk and cream were purchased on the supermarket in Maringa. All reagents used were of analytical grade.

\subsection{Moringa extract}

Peeled seeds $(1 \mathrm{~g})$ were mixed with $10 \mathrm{~mL}$ of sodium chloride $1.0 \mathrm{M}$ and triturated in a blender for 30 seconds, followed by $30 \mathrm{~min}$ of magnetic stirring. Right after, the extract was filtered on a vacuum filter with $0.45 \mu \mathrm{m}$ cellulose ester membrane. Finally, the extract was purified in Millipore ${ }^{\circledR}$ pellicon2mini ultrafiltration system (flow 1 bar, $5 \mathrm{kDa}$ polyurea membrane and $0.056 \mathrm{~m} 2$ filter area). The concentrate was used in the elaboration of the processed cheese.

\subsection{Processing of processed cheese}

The curd mass was obtained by heating pasteurized whole milk at $80{ }^{\circ} \mathrm{C}$ and subsequent coagulation with $85 \%$ lactic acid $(0.28 \% \mathrm{v} / \mathrm{v})$. The milk was maintained under slow and continuous stirring until complete mixing of the acid. Then, the curds were drained and washed with filtered water until reach $\mathrm{pH}$ 5.2.

Five formulations were prepared (formulation in table 1): Con, T1, T2, T3, and T4. The curd mass, fondant salt, sodium chlorate, xanthan gum, and some water were mixed and heated on Thermomix Vorwerk $\left(75^{\circ} \mathrm{C} / 4 \mathrm{~min}\right)$. Thereafter, the cream, remaining water and the extract were added under constant stirring until the temperature reached $90{ }^{\circ} \mathrm{C}$. The treatments were defined as follows: control with $0.5 \%$ of xanthan gum (Con); $0.25 \%$ gum and $0.25 \%$ Moringa extract (T1); $0.5 \%$ Moringa extract (T2); $0.35 \%$ gum and $0.15 \%$ Moringa extract (T3) $0.15 \%$ gum and $0.35 \%$ Moringa extract (T4). Each sample was individually packed in sterile plastic containers and stored at $4{ }^{\circ} \mathrm{C}$. Samples were randomly taken at $1,7,14$ and 21 days of storage for analysis.

Table 1. Processed cheese formulation.

\begin{tabular}{lccccc}
\hline Ingredients (\%) & \multicolumn{5}{c}{ Processed Cheese } \\
\cline { 2 - 6 } & $\begin{array}{c}\text { Con } \\
(\mathbf{0 . 5 \%} \\
\text { gum) }\end{array}$ & $\begin{array}{c}\text { T1 (0.25\% } \\
\text { gum, 0.25\% } \\
\text { Moringa) }\end{array}$ & $\begin{array}{c}\text { T2 (0.5 \% } \\
\text { Moringa) }\end{array}$ & $\begin{array}{c}\text { T3 (0.35\% } \\
\text { gum, 0.15 \% } \\
\text { Moringa) }\end{array}$ & $\begin{array}{c}\text { T4 (0.15\% } \\
\text { gum, 0.35\% } \\
\text { Moringa) }\end{array}$ \\
\hline Curd Mass & 40 & 40 & 40 & 40 & 40 \\
Cream & 37 & 37 & 37 & 37 & 37 \\
Filtered water & 21.3 & 21.3 & 21.3 & 21.3 & 21.3 \\
Fondant salt & 0.6 & 0.6 & 0.6 & 0.6 & 0.6 \\
Sodium chloride & 0.6 & 0.6 & 0.6 & 0.6 & 0.6 \\
Nisin & 0.003 & 0.003 & 0.003 & 0.003 & 0.003 \\
Xanthan gum & 0.5 & 0.25 & - & 0.35 & 0.15 \\
Moringa Extract & - & 0.25 & 0.5 & 0.15 & 0.35 \\
\hline
\end{tabular}

Source: Author. 


\subsection{Chemical composition}

The moisture and ash content were determined according to the Association of Official Analytical Chemists. The protein content was obtained by the micro Kjeldahl method Total lipids were extracted using the method of Gerber. Total carbohydrate was calculated by difference. (AOAC, 2019).

\subsection{Color}

Color was evaluated using a portable colorimeter (Minolta CR400) witha $10^{\circ}$ view angle and a D65 illuminant. Color was determined at nine points, recording lightness $\left(\mathrm{L}^{*}\right)$, redness $\left(\mathrm{a}^{*}\right)$ and yellowness $\left(\mathrm{b}^{*}\right)$.

\subsection{Titratable Acidity and $\mathrm{pH}$}

Titratable acidity was obtained by titration with $0.1 \mathrm{NaOH}$. The $\mathrm{pH}$ was measured using a $\mathrm{pH}$ meter (pHmeter Thermo - Scientific VSTAR 92 Orion Versastar) (AOAC, 2019).

\subsection{Texture}

The parameters of hardness, adhesiveness, elasticity and cohesiveness were determined using a CT3 texture analyzer (Brookfield Engineering laboratories, Inc., Middleboro, USA), equipped with a cylindrical acrylic probe (35 mm). The texturometer was adjusted with a $5 \mathrm{~kg}$ load cell and pre-test speeds, test and post-test: $2.0 \mathrm{~mm} / \mathrm{s}, 10 \mathrm{~mm}$ distance, with 5 seconds of contact time and contact force of $100 \mathrm{~g}$ (Dender et al., 2012).

\subsection{Rheology}

The rheological measurements were carried out according Felix et al., (2017), which was performed $10{ }^{\circ} \mathrm{C}$ using a MARS II controlled stress rheometer (Hacke Thermo Fisher Scientific Inc., Newington, Germany), equipped with a $35 \mathrm{~mm}$ diameter cone plate with a $0.052 \mathrm{~mm}$ gap. The analysis was performed in triplicate for each formulation at $10{ }^{\circ} \mathrm{C}$. The shear rate ranged from 0 to $100 \mathrm{~s}^{-1}$. Data from flow curves were fitted to the Herschel-Bulkley model (Eq. 1) by non-linear regression analysis using Origin Pro 9.1 (Origin Lab Corporation, Northampton, MA, USA).

$\sigma=\sigma_{0} \cdot K \cdot \gamma^{n}$

where $\sigma$ represents the shear stress $(\mathrm{Pa}), k$ is the consistency index $\left(\mathrm{Pa} \cdot \mathrm{s}^{\mathrm{n}}\right), \gamma^{\cdot}$ is the shear rate $\left(\mathrm{s}^{-1}\right)$, and $\mathrm{n}$ represents the consistency index (dimensionless).

\subsection{Scanning electron microscopy}

The surface morphology of the processed cheese was observed through a scanning electron microscope (Quanta 250, FEI, Germany) at $20 \mathrm{kV}$. The samples were fixed on a double-sided carbon tape and coated with a gold layer, with a thickness of approximately $30 \mathrm{~nm}$ (Ahuja, 2017).

\subsection{Statistical analysis}

All experiments were performed with four treatments in triplicate. The processed cheese characteristics were assessed by analysis of variance using the general linear model (GLM) with SPSS (v.15.0) (IBM SPSS Statistics, SPSS Inc., Chicago, EUA) for Windows. Means and standard deviation were calculated for each variable. Differences between means were evaluated by Tuckey test $(\mathrm{p}<0.05)$. 


\section{Resultados e Discussão}

\subsection{Chemical composition}

Processed cheese chemical composition is shown in Table 2, where protein, fat, moisture, ash and carbohydrates were analyzed.

Table 2. Chemical composition of all processed cheese formulations.

\begin{tabular}{cccccc}
\hline Analysis & Con & T1 & T2 & T3 & T4 \\
\hline Protein & $5.51^{\mathrm{c}} \pm 0.005$ & $5.41^{\mathrm{d}} \pm 0.005$ & $5.82^{\mathrm{a}} \pm 0.005$ & $5.71^{\mathrm{b}} \pm 0.005$ & $5.59^{\mathrm{c}} \pm 0.005$ \\
\hline Fat & $19.88^{\mathrm{b}} \pm 0.080$ & $19.16^{\mathrm{c}} \pm 0.065$ & $18.56^{\mathrm{d}} \pm 0.060$ & $18.49^{\mathrm{d}} \pm 0.090$ & $21.07^{\mathrm{a}} \pm 0.075$ \\
\hline Moisture & $67.59^{\mathrm{b}} \pm 0.005$ & $69.59^{\mathrm{a}} \pm 0.348$ & $71.37^{\mathrm{a}} \pm 0.444$ & $71.31^{\mathrm{a}} \pm 0.178$ & $68.51^{\mathrm{b}} \pm 0.684$ \\
\hline Ash & $1.58^{\mathrm{b}} \pm 0.002$ & $1.54^{\mathrm{b}} \pm 0.023$ & $1.60^{\mathrm{b}} \pm 0.023$ & $1.74^{\mathrm{a}} \pm 0.021$ & $1.73^{\mathrm{a}} \pm 0.040$ \\
\hline Carbohydrate & $5.43 \pm 0.066$ & $4.60 \pm 0.079$ & $2.78 \pm 0.710$ & $2.79 \pm 0.339$ & $2.60 \pm 1.092$ \\
\hline
\end{tabular}

*Means with different letters on the same line are significantly different $(\mathrm{p}<0.05)$. Results are expressed as mean and standard deviation. Source: Authors.

For all treatments, proteins presented a significant difference $(\mathrm{p}<0.05)$, the formulation $\mathrm{T} 2$, with $0.5 \%$ Moringa, showed the highest value, followed by formulation T3, T4, Con, and T1. As expected, adding Moringa resulted in an increase of protein, since the seeds have good nutritional quality, with high protein concentrations, approximately $38 \mathrm{~g} / 100 \mathrm{~g}$, and the extract was purified by ultrafiltration process (Baptista et al., 2015; Gopalakrishnan et al., 2016).

Mahami, Ocloo and Odonkor (2012) reported a significant increase in protein content on cottage cheese by adding Moringa seeds extract $(0.5,1,1.5$ and $2 \%)$. Considering the high protein content of Moringa seeds, its use on dairy products is justified by the increase on the yield on the final product because processed cheese is formed by the coagulation of proteins in milk, thus the higher protein content on the extract may increase the final yield (Ogunsina et al., 2011).

Regarding the fat content, a significant difference was observed between the samples. The T4 sample had the highest fat content (21.07), followed by Con, T1, T2 and T3 samples with fat contents of 19.88, 19.16, 18.56 and 18.49 respectively. In addition, the formulation containing only extract (T2) and the formulation containing $0.35 \%$ of gum and $0.15 \%$ of Moringa (T3) did not show a significant difference between them. This result was expected, since the ultrafiltration membrane retains components of high molecular mass, such as fat (Cunha et al., 2010).

Felix et al. (2016) studied the effect of adding konjac gum on cheese, and conclude that formulations with lower fat cheese showed an increase in moisture. A similar fact was observed in this study, where fat and moisture contents were inversely correlated, T2 was the sample with the highest fat content followed by T3, T1, T4, and Con, respectively. Higher moisture content contributes to the reduction of the defatted dry extract (DDE). The high casein content contained in the DDE promotes the strengthening of the protein-protein interactions, causing the protein matrix to stiffen and, thus, to reduce the creaminess of the processed cheese (Silva, 2012).

The mineral content of the samples differed significantly $(\mathrm{p}<0.05$ ), where the $\mathrm{T} 1$, Con and $\mathrm{T} 2$ formulations had the lowest values of 1.58, 1.54 and 1.60 respectively. The values found on this study were lower than the ones reported by Dender et al., (2012), who found values ranging from 2.52 to $2.57 \%$ in their processed cheese without fat addition and reduced sodium content. Regarding the carbohydrate content, there was no difference between the formulations. However, all formulations presented a high carbohydrate content when compared to a typical processed cheese, which the carbohydrate content is about $1.2 \%$ (Dender et al., 2012). 


\subsection{Color}

The results of the color analysis are presented in Table 3. The samples presented high $\mathrm{L}$ values and low values for the parameter $\mathrm{a} *$, indicating a trend of the samples for green color, while the parameter $\mathrm{b} *$ the values were positive, indicating a trend towards a yellow color. There were significant differences ( $p>0.05$ ) between the samples in relation to the parameters. The addition of the Moringa had a significant effect on luminosity, yellowness $(\mathrm{b} *)$ and redness values $(\mathrm{a} *)$.

Table 3. Instrumental color of processed cheese.

\begin{tabular}{lllllll}
\hline Parameter & Con & T1 & T2 & T3 & T4 & P<0,05 \\
\hline L & $101.11^{\mathrm{a}} \pm 0.413$ & $88.13^{\mathrm{c}} \pm 0.989$ & $90.35^{\mathrm{c}} \pm 0.502$ & $98.56^{\mathrm{ab}} \pm 0.046$ & $96.74^{\mathrm{b}} \pm 0.837$ & 0.000 \\
\hline $\mathrm{a}^{*}$ & $0.27^{\mathrm{a}} \pm 0.015$ & $0.14^{\mathrm{b}} \pm 0.036$ & $0.13^{\mathrm{c}} \pm 0.019$ & $0.19^{\mathrm{ab}} \pm 0.008$ & $0.12^{\mathrm{b}} \pm 0.018$ & 0.000 \\
\hline $\mathrm{b}^{*}$ & $11.36^{\mathrm{c}} \pm 0.032$ & $13.31^{\mathrm{ab}} \pm 0.184$ & $13.43^{\mathrm{a}} \pm 0.147$ & $13.22^{\mathrm{ab}} \pm 0.022$ & $12.63^{\mathrm{b}} \pm 0.104$ & 0.000
\end{tabular}

* Means with different letters on the same line are significantly different $(\mathrm{p}<0.05)$. Results are expressed as mean and standard deviation. Source: Authors.

The differences among the samples may be explained by the use of the gum and extract since the differences tend to increase with the increase of the use of the gum substitute. Cunha et al (2010) observed a similar behavio in his study when worked with cheese analogue produced with vegetable fat, and the color variation was directly correlated with the addition of the vegetable fat.

\subsection{Titratable Acidity and pH}

Milk is considered a buffer system with a low concentration of free hydrogen ion, thus its total amount of acid can be obtained only by the titratable acidity measure (Dender et al 2012). Titrable acidity and pH values are shown in table 4 . Titratable acidity significantly differed ( $p>0.05$ ) only at 21 days of storage, where T3 showed the highest acidity (0.094), followed by samples T4, T1, Con, and T2 with $0.088,0.084,0.080$ and 0.059 respectively.

The treatment added only with Moringa, T2, presented the lowest acidity values throughout storage. Moringa seeds extract may have inhibited the growth of lactic acid microorganisms resulting in the reduction of the amount of acid produced, due to its antimicrobial properties (Mahami; Ocloo; Odonkor., 2012). 
Research, Society and Development, v. 10, n. 4, e54010414381, 2021

(CC BY 4.0) | ISSN 2525-3409 | DOI: http://dx.doi.org/10.33448/rsd-v10i4.14381

Table 4. Titratable acidity and $\mathrm{pH}$ of all processed cheese during storage period.

\begin{tabular}{|c|c|c|c|c|c|c|c|c|}
\hline & Days & Con & T1 & T2 & T3 & T4 & SEM & $\mathrm{p}<0.05$ \\
\hline \multicolumn{9}{|c|}{ Titratable Acidity } \\
\hline & 1 & 0.027 & 0.031 & 0.020 & $0.027^{\mathrm{B}}$ & 0.027 & 0.001 & 0.101 \\
\hline & 7 & 0.080 & 0.066 & 0.062 & $0.065^{\mathrm{B}}$ & 0.061 & 0.003 & 0.543 \\
\hline & 14 & 0.088 & 0.080 & 0.066 & $0.071^{\mathrm{B}}$ & 0.075 & 0.003 & 0.480 \\
\hline & 21 & $0.080^{\mathrm{b}}$ & $0.084^{\mathrm{ab}}$ & $0.059^{c}$ & $0.094^{\mathrm{aA}}$ & $0.088^{\mathrm{ab}}$ & 0.004 & 0.002 \\
\hline SEM & & 0.003 & 0.003 & 0.002 & 0.004 & 0.004 & & \\
\hline $\mathrm{p}<0.05$ & & 0.811 & 0.392 & 0.536 & 0.005 & 0.075 & & \\
\hline \multicolumn{9}{|l|}{ pH } \\
\hline & 1 & $6.365^{\mathrm{A}}$ & $6.395^{\mathrm{A}}$ & $6.415^{\mathrm{A}}$ & $6.400^{\mathrm{A}}$ & $6.370^{\mathrm{A}}$ & 0.007 & 0.113 \\
\hline & 7 & $6.350^{\mathrm{bcA}}$ & $6.385^{\mathrm{a} A}$ & $6.380^{\mathrm{abA}}$ & $6.350^{\mathrm{bcB}}$ & $6.335^{\mathrm{cB}}$ & 0.006 & 0.031 \\
\hline & 14 & $6.365^{\mathrm{A}}$ & $6.390^{\mathrm{A}}$ & $6.390^{\mathrm{A}}$ & $6.355^{\mathrm{B}}$ & $6.370^{\mathrm{A}}$ & 0.005 & 0.103 \\
\hline & 21 & $6.235^{\mathrm{abB}}$ & $6.240^{\mathrm{aB}}$ & $6.240^{\mathrm{aB}}$ & $6.195^{\mathrm{bC}}$ & $6.155^{\mathrm{cC}}$ & 0.011 & 0.012 \\
\hline SEM & & 0.021 & 0.024 & 0.026 & 0.029 & 0.033 & & \\
\hline $\mathrm{p}<0.05$ & & 0.000 & 0.000 & 0.001 & 0.001 & 0.000 & & \\
\hline
\end{tabular}

*Means in the same line with the same lower case overwritten are not significantly different $(\mathrm{p}<0.05)$. Means in the same column with the same upper case letter overwritten are not significantly different $(\mathrm{p}<0.05)$. Source: Authors.

The $\mathrm{pH}$ is an important parameter of cheese identity and quality, once it directly affects the cheese structure and rheological properties (Belsito et al., 2017). pH values below 5.4 may indicate damage to the structure of the melted cheeses since they tend to form a very firm and granular texture, as well as to promote flavor changes. On the other hand, $\mathrm{pH}$ between 5.5 and 5.7 results in cheese with a creamy and firm consistency. Processed cheese showed pH higher than 6.0, as a result of the decrease in the protein-protein interaction and the increase of the protein hydration, causing less firm curd and thus altering

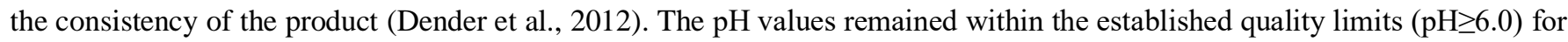
all samples during the 21 days of storage. The variation of $\mathrm{pH}$ and titratable acidity of cream cheese is related to the composition of the products (Felix et al., 2017).

\subsection{Texture}

Texture results are shown in Table 5. It was observed statistical differences $(p<0.05)$ for hardness during all days. Cohesiveness showed differences at day 1 and 14, adhesiveness at days 7, 14, and 21, and elasticity at day 7 and 14 . 
Table 5. Evaluation of texture parameter during storage period.

\begin{tabular}{|c|c|c|c|c|c|c|c|c|}
\hline & Days & Con & T1 & T2 & T3 & T4 & SEM & $p<0.05$ \\
\hline \multicolumn{9}{|c|}{ Hardness } \\
\hline & 1 & $227.500^{\mathrm{a}}$ & $92.500^{\mathrm{cBC}}$ & $32.500^{\mathrm{d}}$ & $142.500^{b}$ & $212.500^{\mathrm{a}}$ & 24.42 & 0.001 \\
\hline & 7 & $222.500^{\mathrm{a}}$ & $85.000^{\mathrm{cC}}$ & $32.500^{\mathrm{d}}$ & $137.500^{b}$ & $222.500^{\mathrm{a}}$ & 25.07 & 0.001 \\
\hline & 14 & $265.000^{\mathrm{a}}$ & $90.000^{\mathrm{cAB}}$ & $32.500^{\mathrm{d}}$ & $157.500^{c}$ & $215.000^{\mathrm{b}}$ & 28.29 & 0.001 \\
\hline & 21 & $243.000^{\mathrm{b}}$ & $105.000^{\mathrm{dA}}$ & $30.500^{\mathrm{e}}$ & $155.000^{c}$ & $243.500^{\mathrm{a}}$ & 25.82 & 0.001 \\
\hline SEM & & 7.043 & 2.978 & 0.886 & 3.651 & 3.659 & & \\
\hline$p<0.05$ & & 0.076 & 0.028 & 0.884 & 0.108 & 0.847 & & \\
\hline
\end{tabular}

\section{Cohesiveness}

\begin{tabular}{|c|c|c|c|c|c|c|c|c|}
\hline & 1 & $0.850^{\mathrm{a}}$ & $0.860^{\mathrm{a}}$ & $0.515^{\mathrm{b}}$ & $0.720^{\mathrm{b}}$ & $0.770^{\mathrm{a}}$ & 0.043 & 0.006 \\
\hline & 7 & 0.770 & 0.815 & 0.845 & 0.830 & 0.720 & 0.018 & 0.126 \\
\hline & 14 & $0.920^{\mathrm{a}}$ & $0.955^{\mathrm{a}}$ & $0.555^{\mathrm{b}}$ & $0.835^{\mathrm{ab}}$ & $0.760^{\mathrm{ab}}$ & 0.051 & 0.029 \\
\hline & 21 & 0.860 & 0.860 & 0.850 & 0.885 & 0.740 & 0.045 & 0.931 \\
\hline SEM & & 0.034 & 0.032 & 0.070 & 0.036 & 0.013 & & \\
\hline $\mathrm{p}<0.05$ & & 0.612 & 0.592 & 0.149 & 0.537 & 0.692 & & \\
\hline
\end{tabular}

\begin{tabular}{|c|c|c|c|c|c|c|c|c|}
\hline \multicolumn{9}{|c|}{ Adhesiveness } \\
\hline & 1 & 3.500 & $1.950^{\mathrm{C}}$ & $0.001^{\mathrm{B}}$ & 3.000 & 5.250 & 0.670 & 0.094 \\
\hline & 7 & $5.250^{\mathrm{a}}$ & $2.800^{\mathrm{bBC}}$ & $0.299^{\mathrm{cA}}$ & $4.100^{\mathrm{ab}}$ & $3.150^{\mathrm{b}}$ & 0.556 & 0.000 \\
\hline & 14 & $9.550^{\mathrm{a}}$ & $2.350^{\mathrm{bcB}}$ & $0.350^{\mathrm{cA}}$ & $3.500^{\mathrm{b}}$ & $2.950^{\mathrm{bc}}$ & 1.044 & 0.000 \\
\hline & 21 & $5.200^{\mathrm{a}}$ & $4.290^{\mathrm{abA}}$ & $0.300^{\mathrm{cA}}$ & $4.400^{\mathrm{ab}}$ & $2.700^{\mathrm{ab}}$ & 0.595 & 0.002 \\
\hline SEM & & 0.885 & 0.338 & 0.053 & 0.233 & 0.577 & & \\
\hline $\mathrm{p}<0.05$ & & 0.014 & 0.000 & 0.002 & 0.095 & 0.461 & & \\
\hline \multicolumn{9}{|c|}{ Elasticity } \\
\hline & 1 & 6.045 & $6.210^{\mathrm{C}}$ & 8.645 & $6.285^{\mathrm{C}}$ & 6.790 & 0.427 & 0.313 \\
\hline & 7 & $6.305^{\mathrm{ab}}$ & $6.195^{\mathrm{abC}}$ & $5.360^{\mathrm{b}}$ & $6.485^{\mathrm{abC}}$ & $6.690^{\mathrm{a}}$ & 0.165 & 0.033 \\
\hline & 14 & $6.415^{\mathrm{ab}}$ & $6.685^{\mathrm{abB}}$ & $5.770^{\mathrm{b}}$ & $7.230^{\mathrm{aA}}$ & $6.400^{\mathrm{ab}}$ & 0.595 & 0.036 \\
\hline & 21 & 6.370 & $7.110^{\mathrm{A}}$ & 5.790 & $6.715^{\mathrm{B}}$ & 6.745 & 0.177 & 0.138 \\
\hline SEM & & 0.093 & 0.143 & 0.596 & 0.135 & 0.218 & & \\
\hline $\mathrm{p}<0.05$ & & 0.612 & 0.000 & 0.160 & 0.001 & 0.956 & & \\
\hline
\end{tabular}

*Means in the same line with the same lower case overwritten are not significantly different $(\mathrm{p}<0.05)$. Means in the same column with the same upper case letter overwritten are not significantly different $(\mathrm{p}<0.05)$. SEM - mean standard deviation. Source: Authors.

The results obtained in the evaluation of the texture of the creamy curd are shown in Table 5. Statistical differences (p $<0.05)$ can be observed for the firmness parameter in all the days analyzed. The other parameters showed differences on days 1 and 14 for cohesiveness, days 7.14 and 21 for adhesiveness and on days 7 and 14 for elasticity. Throughout the storage period, only the T1 sample differed between storage days for firmness. Adhesiveness differed for samples Con, T1 and T2 and elasticity for samples T1 and T3 during storage days. The samples showed no significant differences during storage for cohesiveness.

Changes in the texture profile can happen during storage due to activities such as proteolysis, glycolysis, lipolysis and $\mathrm{pH}$ changes. Proteolysis can occur during cheese storage due to changes in the texture of this product, as there is a break in its protein matrix, destabilizing the texture, firmness, adhesiveness and elasticity (Mattanna et al., 2012). 
Regarding firmness, the control cheese and the T4 sample were firmer than the others. The T2 sample showed less firmness compared to the others on days 1,7 and 14 of storage. Moisture plays an important role in the technological processing of curd, since it influences the firmness of the final product (Silva, 2012). High humidity values weaken the protein's stiffness contributing to the softness of the curd (Cunha et al., 2010). In addition, complexes formed from proteins with polysaccharides can improve emulsifying properties, as they contribute to texture improvement (Felix et al., 2017). According to Mattanna et al. (2012) a number of factors can influence the texture of processed cheeses, including composition, $\mathrm{pH}$, type and concentration of emulsifying salt, in addition to the parameters used in processing, such as agitation and temperature.

\subsection{Rheology}

The samples showed a non-Newtonian behavior and the shear rate curves were mathematically modeled using the Herschel-Bulkley model, with the parameters presented in Table 6. We can observe that the data fit the model, since for all treatments, $\mathrm{R}^{2}$ was superior than 0.95 .

Table 6. Herschel-Bulkley Model Parameters.

\begin{tabular}{lllll}
\hline Treatment & $\sigma_{\mathbf{0}}$ & $\begin{array}{l}\mathbf{K} \\
\left(\text { Pa.s }^{\mathbf{n}}\right)\end{array}$ & $\boldsymbol{n}$ & $\mathbf{R}^{\mathbf{2}}$ \\
\hline Con & 10.53 & 52.59 & 0.303 & 0.991 \\
\hline T1 & 4.393 & 10.55 & 0.578 & 0.996 \\
\hline T2 & 28.66 & 5.70 & 0.746 & 0.998 \\
\hline T3 & 7.33 & 29.83 & 0.399 & 0.996 \\
\hline T4 & 13.56 & 94.42 & 0.239 & 0.966 \\
\hline
\end{tabular}

Source: Authors.

Observing flow behavior index $(n)$, all are smaller than one $(\mathrm{n}<1)$, in accordance with literature data, corroborating to classify the fluid as non-Newtonian and shear-thinning (pseudoplastic) behavior. The highest consistency index (K) was calculated for sample T4, followed by samples Con, T3, T1, and T2, respectively. Sample T2 presented the highest value for the yield stress $\left(\sigma_{0}\right)$, which was quite high in relation to the others, and this high value could be associated to a concomitant increase in protein hydration, viscosity, and consistency (Kelimu et al., 2017).

Rheological differences may be explained by the composition of the formulations and the interactions of the particles, due to the partial or total substitution of the thickener by the Moringa extract that acts on the viscosity of the product (Belsito et al., 2017). Low fat content may be responsible for changes in texture. Once there is a fat reduction, there is an increase in protein-protein interaction, causing the stiffening of the protein matrix and, thus, a decrease in the creaminess of processed cheese (Silva, 2012). The flow curves of the samples at $10^{\circ} \mathrm{C}$ are shown in Figure 1. 
Figure 1. Rheological behavior of processed cheese formulations.

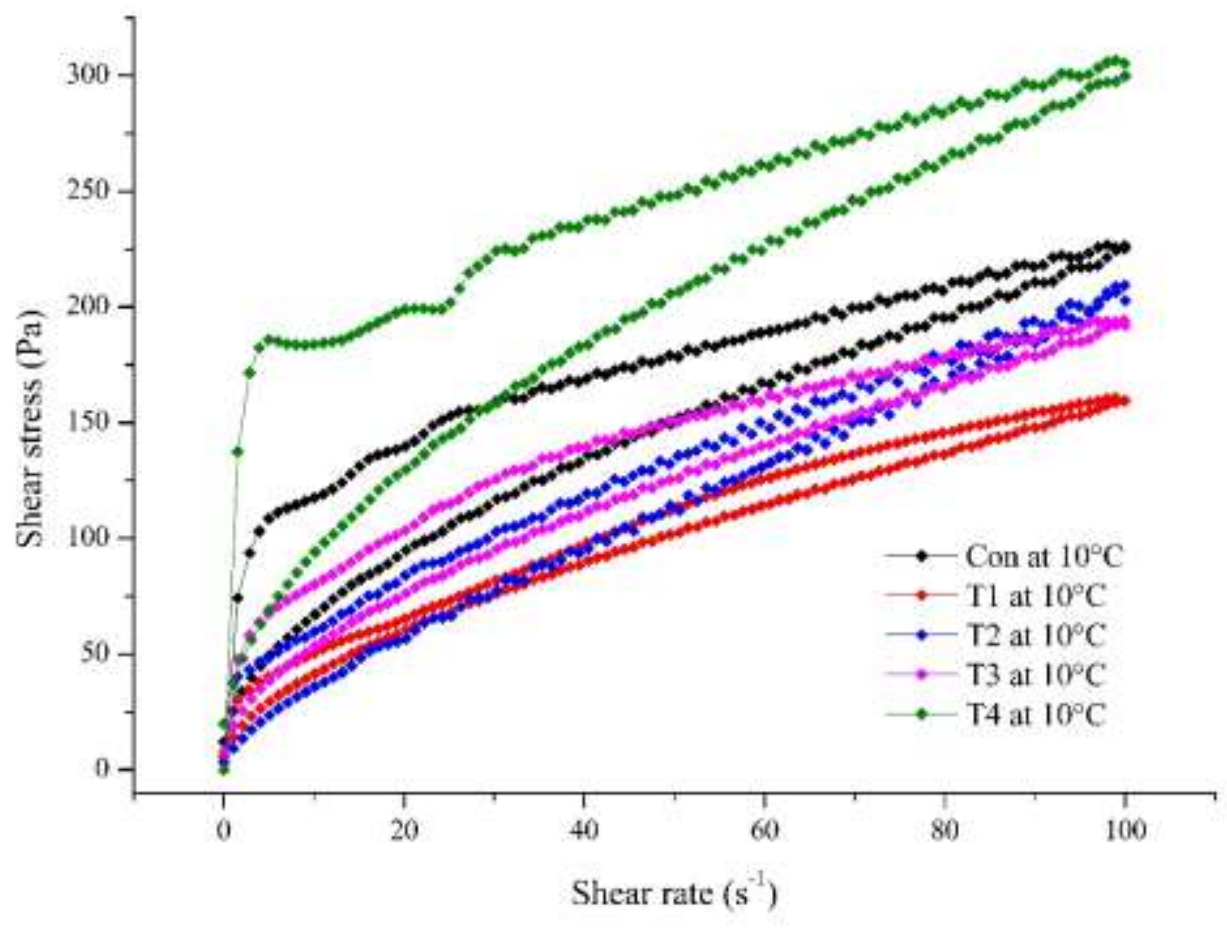

Source: Authors.

When analyzing Figure 1 we can observe that all the samples had thixotropic characteristics, as a function of the difference of tension and viscosity shown in the ascending and descending curves. This phenomenon can be explained by the change of viscosity when a shear force is applied to gel network. Initially, the gel tends to resist the shear force, thus only the deformation occurs (Felix et al., 2017).

\subsection{Scanning electron microscopy}

Figure 2 shows the micrographs of the microstructure of the processed cheese, with magnitudes of approximately $500 X$. 
Figure 2. Micrographs of the microstructure of the processed cheese.
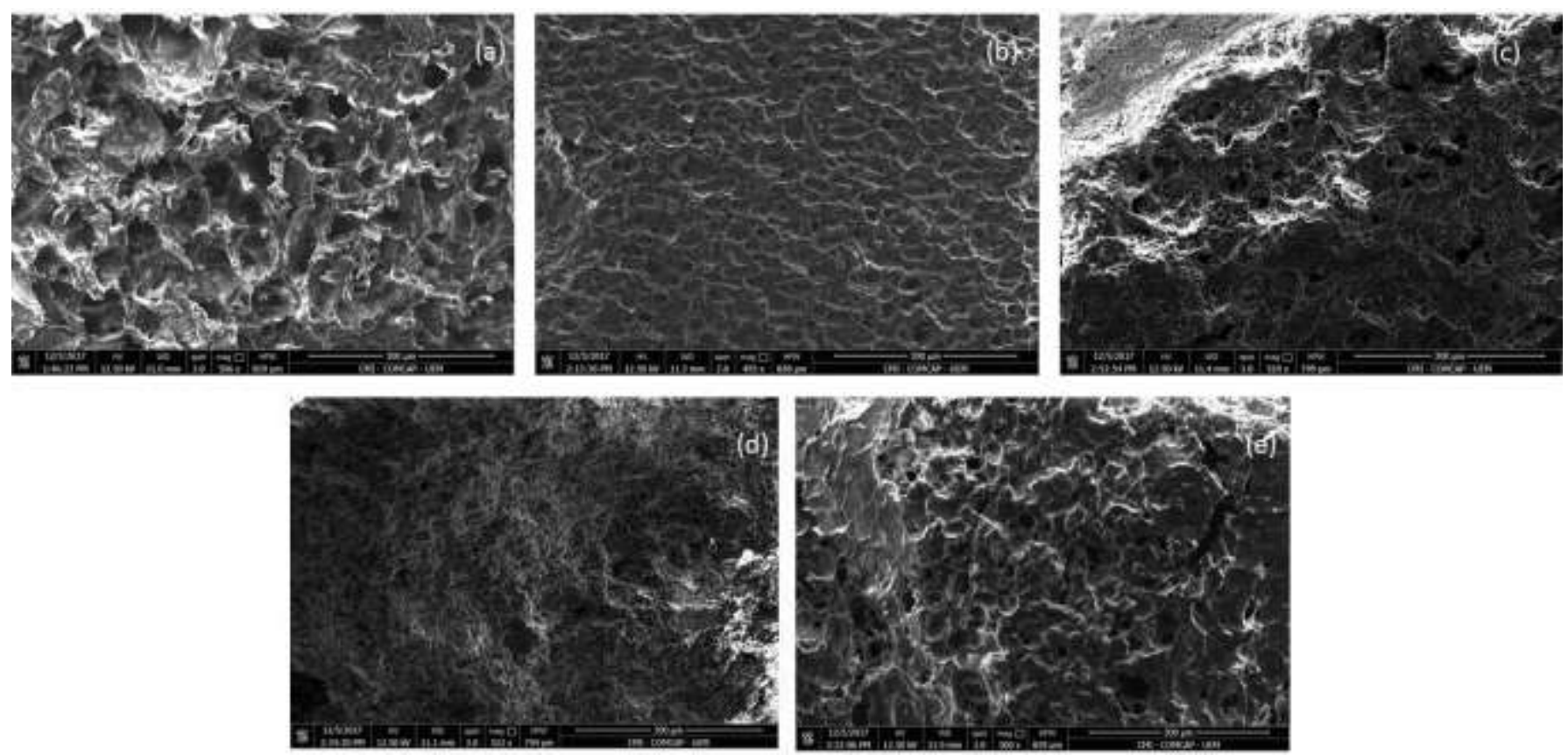

Source: Authors.

The same type of structure in all samples was observed. The control sample (Figure 2 (a)) showed dispersed fat particles in a uniform protein network, where the fat globules are predominantly spherical and evenly distributed throughout the protein matrix. On the other hand, in the groups with the addition of the extract, the fat globules presented particle size with smaller diameters. In addition, they were distributed less uniformly in the protein matrix. Comparing the microstructure of the processed cheese with the addition of Moringa extract (Figure 2 (a), (b), (c) and (d)) with control, there was an increase in the number of fat globules and a decrease in their diameters.

The size of the particles is directly related to the rate of rupture, which depends on the shear force applied during processing, as well as the composition of fatty acids and the structure of the fat network (Cunha et al., 2010). This decrease in size/diameter of the fat globules may indicate that the emulsion process occurred and thereby the breakage and dispersion of the extract/gum in the mass. Considering that during processing, stirring and heating favored the rupture of those fat globules, the smaller particles formed could be more easily emulsified by casein (Felix et al., 2016).

\section{Conclusão}

The main conclusions are related to the rheological aspects and texture parameters of the processed cheese. The Moringa extract interfered in the texture of the product, proving to be a great partial and/or total substitute of chemical preservatives. The sample with greater gum substitution by the Moringa extract had hardness equal to the control sample. Also, this sample (T4- $0.15 \%$ gum and $0.35 \%$ Moringa extract) presented higher consistency index (K). Samples did not show significant differences during storage period for cohesiveness. Thus, it is believed that the Moringa seed has a potential for use as a gum substitute, its application in other types of cheeses, yoghurts and dairy desserts can be explored.

\section{Agradecimentos}

The authors thank the State University of Maringá (UEM) and the Higher Education Personnel Improvement Coordination (CAPES) - Financing Code 001. 


\section{Referências}

AOAC (1990) Official methods of analysis (15th ed.). Association of Official Analytical Chemists.

Baptista, A. T. A., Coldebella, P. F., Cardines, P. H. F., Gomes, R. G., Vieira, M. F., Bergamasco, R. \& Vieira, A. M. S. (2015) Coagulation-flocculation process with ultrafiltered saline extract of moringa oleifera for the treatment of surface water. Chemical Engineering Journal, 276, 166-173.

Baptista, A. T. A., Silva, M. O., Gomes, R. G., Bergamasco, R., Vieira, M. F. \& Vieira, A. M. S. (2017) Protein fractionation of seeds of Moringa oleifera lam and its application in superficial water treatment. Separation and Purification Technology, 180, 114-124.

Belsito, P. C., Ferreira, M. V. S., Cappato, L. P., Cavalcanti, R. N., Vidal, V. A. S., Pimentel, T. C., Esmerino, E. A., Balthazar, C. F., Neto, R. P. C., Tavares, M. I. B., Zacarchenco, P. B., Freitas, M. Q., Silva, M. C., Raices, R. S. L., Pastore, G. M., Pollonio, M. A. R. \& Cruz, A. G. (2017) Manufacture of Requeijão cremoso processed cheese with galactooligosaccharide. Carbohydrate Polymers, 174, 869-875.

Colin-Cruza, M. A., Pimental-Gonzalez, D. J., Camillo-Navasc, H., Alvarez-Ramirez, J. \& Guadarram-Lezama, A. Y. (2019) Co-encapsulation of bioactive compounds from blackberry juice andprobiotic bacteria in biopolymeric matrices. LWT - Food Science and Technology, 110, 94-101.

Cunha, C. R., Dias, A. I. \& Viotto, W. H. (2010). Microstructure, texture, colour and sensory evaluation of a spreadable processed cheese analogue made with vegetable fat. Food Research International, 43, 723-729.

Dender, A. G. F., Spadotti, L. M., Zazarchenco, P. B. \& Trenco, F. K. H. S. (2012) Effects of emulsifying salts on the characteristics of processed cheese without added fat and reduced sodium. Revista do Instituto de Laticínios Cândido Tostes, 67,38-47.

Felix, S. D., Ferreira, S. B. S., Brusch, M. L., Britten, M \& Matumoto-Pintro, P. T. (2016) Effect of commercial konjac glucomannan and konjac flours on textural, rheological and microstructural properties of low fat processed cheese. Food Hydrocolloids, 60, 308-316.

Felix, S. D., Junior, N. N. T., Gomes, R. G., Pozza, M. S. S., Britten, M \& Pintro-Matumoto, P. T. (2017) Physical, microbiological and rheological properties of probiotic yogurt supplemented with grape extract. Journal of Food Science and Technology, 54, 1608-1615.

Gopalakrisnan, L., Doriya, K. \& Kumar, D. S.(2016) Moringa oleifera: A review on nutritive importance and its medicinal application.Food Science and Human Wellness, 5, 49-56.

Gupta, S., Jain, R., Kachwaha, S. \& Kothari, S. L. (2017) Nutritional and medicinal applications of Moringa oleifera Lam: Review of current status and future possibilities. Journal of Herbal Medicine, 54, 43-52.

Kelimu, A., Felix, S. D., Geng. X., Ipsen, R. \& Hougaard, A. B. (2017) Effects of different dairy ingredients on the rheolog ical behaviour and stability of hot cheese emulsions. International Dairy Journal, 71, 35-42.

Mahami, T., Ocloo, F. \& Odonkor, S. (2012) Preliminary study on the influence of moringa seed extracts supplementation on the yield and quality of cottage cheese. International Journal of Recent Trends in Science And Technology 2(1), 4-8.

Mao, L., Miao, S., Yuan, F. \& Gao, Y. (2018) Study on the textural and volatile characteristics of emulsion filled protein gels as in fluenced by different fat substitutes. Food Research International, 103, 1-7.

Mattanna., P., Richards, N. S. P. S., Back, D. \& Gusso, A. P. (2012) Parâmetros Tecnológicos e Sensoriais de Requeijões Cremosos com baixo teor de lactose , Revista do Instituto de Laticínicos Cândido Tostes, 67 (387), 30-37

Ogunsina, B. S., Radha, C. \& Indrani, D. (2011) Quality characteristics of bread and cookies enriched with debittered Moringa oleifera seed flour. International Journal of Food Sciences and Nutrition, 62, 185-194.

Silva, R. C. S. N. S., Minin, V. P. R., Lima, L. P., Gomide, A. I., Moraes, L. E. S. \& Minin, L. A. (2012) Otimização da aceitabilidade sensorial de requeijão cremoso. Ciência Rural, 42, 360-366.

Torres, S. A., Spadoti, A. L. M., Blumer, P., Zacarchenco, P. B. \& Van Dender, A. G. F. (2015). Desenvolvimento de Tecnologia de Fabricação de Requeijão Cremoso com Teor Reduzido de Gordura. Revista do Instituto de Laticínios Cândido Tostes , 70(2), 1-14.

Vieira, M. C., Ccavichiolo, J. R., Van Dender, M., Spadoti, L. M., Zazarchenco, P. B., Gomes, R. A. R. \& Van Dender, A. G. F. (2014) Análise de viabilidade econômica da produção de formulações de requeijão cremoso sem adição de gordura e com teor reduzido de sódio. Informações Econômicas, 44(3), 36-50

Yeh, H., Chuang, C., Chen, H., Wan, C. J., Chenm, T. L. \&, Lin, L. Y. (2014) Bioactive components analysis of two various gingers (Zingiber officinale Roscoe) and antioxidant effect of ginger extracts. LWT - Food Science and Technology, 55(1), 329-334. 